\title{
Nathanael Pringsheim and the foundation of the Biologische Anstalt Helgoland
}

\author{
D. Mollenhauer \\ Forschungsinstitut Senckenberg, Außenstelle Lochmühle; 63599 Biebergemünd, \\ Germany
}

\begin{abstract}
Many of the reasons for what people do or do not do can be found within the general sentiment of human society. We are all, to a large extent, products of our time and of our society. For many Germans, large forests and the sea have a fascinating, romantic appeal. Key themes are "Der Freischütz" or "Der fliegende Holländer". During the second half of the nineteenth century, the somewhat belated industrial revolution in central Europe brought prosperity to the middle classes. Ample leisure time and hobbies were no longer privileges of the nobility. The railway system was built. People began to travel for pleasure and recreation. Holidays on the seashore became popular. Industrialization brought with it a decline (or even decay) of the natural environment, the appreciation of which now grew, with its increasing rarity.

Those who are sensitive to the progressive technicalization of almost all aspects of life often express a longing for genuine nature. The sea appeared to have all the qualities of unspoiled nature.

This romanticism and enthusiasm for the naturalness of the seashore is one of many reasons that led to the "run" on Helgoland. After rather a long time-lag of insignificance, Helgoland had become a fashionable seaside resort. Biologists of the higher academic ranks had attained established social positions, and were among the cruise passengers and summer holidaymakers visiting the island.

A further reason for the popularity of Helgoland was nationalism. After centuries without a unified national state, the Germans rather suddenly became citizens of the so-called "second empire" and hastily erected national symbols. Characteristic examples are the Kyffhäuser monument, the "Deutsches Eck" or the Hermann's monument.

The poet Hoffmann von Fallersleben (Borchert 1991) wrote his "Lied der Deutschen" on the rocky island of Helgoland which was his place of exile in the "Vormärz" era in 1841." The popularity of the poem certainly contributed to Helgoland being regarded as a national monument. This is somewhat strange, however, since the inhabitants of this island are a special breed of Friesian people who considered itself a tribe of its own. The people never were enthusiastic Danish, English or Prussians. Nevertheless, in Wilhelminian Germany, Helgolanders and other seaside folk were regarded as being very German.

A further reason for the increased interest in Helgoland was a matter of biology. Phylogenetic biology became a predominant part of popular education during the second part of the 19th century. Many marine organisms were incorporated into the construction of phylogenetic trees. The public had at least heard of these new ideas in current biology of the eighties and 'nineties of the last century. Marine biology became popular (see Florey, this volume). This was the current to swim with in the last quarter of the 19 th century.
\end{abstract}

\footnotetext{
- The Presidents Friedrich Ebert (11th August, 1922) and Theodor Heuss (6th May, 1952) later declared this poem to be the national anthem of the German Republics.
} 
Nathanael Pringsheim was a man of this era. He and many of his relatives were the champions of the epoch. Another member of this large family, Ernst Georg Pringsheim (1881-1970), who also became famous as professor of botany and as phycologist, stated that eight familiy members were important men of German science (Pringsheim 1970).

During the Wilhelminian era, university professors in Germany rose to the top of the social hierarchy; today we only perceive a pale reflection of the former splendour - the title of professor being convenient for job applications, as a minor advertising vehicle or as an additional decoration for members of boards of trustees. The Zeitgeist of the late 19th century in Germany was different from that of today. University professors who were aware of their high influence could become very successful in science politics.

Nathanael Pringsheim was born in 1823 as one of 19 children of a jewish factory owner. His childhood and youth, school and first university studies in Breslau/Wroclaw in Silesia (very Prussian at that time) have been described in detail by Ferdinand Cohn, who was Pringsheim's countryman, friend, colleague and brother-in-faith (Schumann, 1894; Cohn, 1895, 1901; Mollenhauer, 1992). Nathanael was one among the numerous famous scientists who were rather poor at school. He passed his final examination - what we call "Abitur" in German, or "matura" in Austrian German - only with the third attempt. He began his university courses in a rather traditional manner.

However, in Leipzig he studied the epoch-making botany book of his time, Matthias Jakob Schleiden's (1804-1881) "Grundzüge der wissenschaftlichen Botanik" (fundamentals of scientific botany) with the programmatic subtitle "Die Botanik als inductive Wissenschaft behandelt" (botany treated as an inductive science; cf. Schleiden, 1845, 1846). Many historians of science consider this book the starting point of true scientific (or experimental) German botany. Plant science was transformed from natural history into an exact science, on a level with physics or chemistry.

Pringsheim was fascinated and saw his path through life as a botanical investigator clearly before him. His being Jewish was a further motive for his ambitious plans. The German citizens of Mosaic confession were mostly loyal to the Emperor, and, as a whole, they were protagonists of the emancipation of the middle classes. Many Jews received an excellent education and contributed a lot to the progress of science, trade and industry. Nathanael Pringsheim worked out a pathbreaking study of the anatomy of pea seeds which was accepted as a PhD thesis at the modern University of Berlin - then the only university where a Prussian Jew could get a doctorate. Immediately after his graduation, Pringsheim travelled to Britain and France to meet the leading botanists (in particular, phycologists) of these progressive countries, which at that time were trendsetters in botany. Well-informed and well-introduced, Pringsheim concentrated on a study of the ontogeny of lower plants and on the cytology of sexual reproduction in general, mostly worked out by investigations on algae. He was also interested in lower fungi, and presented one such study, viz. on Saprolegnia which qualified him as a university lecturer.

In 1850, Pringsheim received the title of "Privatdozent" of the Royal Prussian University in Berlin, and was also appointed a member of the "Academia Caesarea Leopoldino-Carolino Naturae Curiosorum", the German Academy of Scientists. Ten years later he also became a member of the "Preußische Akademie der Wissenschaften" and was promoted to the rank of Professor. Some years previously, he had been offered the Chair of Schleiden at the University of Jena. Pringsheim only went there for a few 
years. In Jena he established the first laboratory of plant physiology at any German university, and worked out a modern curriculum for botany. However, he had an urge to return to Berlin. He thus went back to Prussia's capital, where he reached the peak of his fame.

Pringsheim was an excellent researcher in his private laboratory where he assembled many promising young scientists around him. He was a charming host who lived in great style and was in social intercourse with most leading scientists in the Berlin of his time. He was a scrupulous observer of the structure and reproduction of lower plants, and a top organizer of science. He edited his own journal, the "Botanische Jahrbücher"; he created "his own society", the "Deutsche Botanische Gesellschaft", whose foundation, (aided by the older "Botanischer Verein der Provinz Brandenburg" and the "Botanische Sektion der Gesellschaft Deutscher Naturforscher und Ärzte") was accomplished through Pringsheim's art of persuasion - in 1882 (cf. Degen, 1974, 1982; Schnarrenberger \& Scholz 1980).

The first meeting-place of the "Deutsche Botanische Gesellschaft" also was a national symbol: Eisenach with the famous Wartburg, connected with many aspects of German history, expecially with Martin Luther's translation of the Latin Bible (1522: New Testament, 1534: Complete Bible) into the language which was to become the present High-German.

In many respects, Nathanael Pringsheim was a perfect example of the German biology professor of the 19th century: he was liberal as well as patriotic; a man of influence, his house was frequently visited by many luminaries of science of his time; an outstanding specialist in his field of research, and a man of international reputation.

Pringsheim was quite familiar with Helgoland, its algae and its people (cf. Heincke 1899). He first went there for a visit in 1852, over a hundred and forty years ago. $\mathrm{He}$ studied algae on the rocky littoral. He repeated and supplemented Alphonse Thuret's (1817-1875) pioneer work on sexuality in Fucus. Pringsheim discussed his studies in phycology with his elder colleague in Berlin, Alexander Braun (1805-1877), who presented most of Pringsheim's papers to the Prussian Academy. He suggested further phycological studies on Helgoland, and many of his colleagues and students came there: Ferdinand Cohn, Leopold Kny, Paul Wilhelm Magnus, Johannes Reinke, and others (Mollenhauer \& Lüning, 1988). Pringsheim and most of his students and colleagues were not simply algae collectors; their chief interest was the structure and reproduction of selected species. Thanks to these investigations, some of the algae they studied on Helgoland became textbook-cases in phycology. Pringsheim's important papers have been listed in the paper by Mollenhauer \& Lüning (1988). His observations and descriptions are reliable to the last detail. In 1984, Kornmann and Sahling could use one such report when discussing a hitherto unreported Sorocarpus species (Kornmann \& Sahling, 1984).

After a long preliminary phase with many different proposals for the establishment of a marine biological station on Helgoland, matters looked promising in 1890, when Helgoland had become a part of Prussia. This was the moment for Pringsheim, together with other influential colleagues, to bring all his authority to bear on making marine biology a matter of "big science".

Thus, marine biology was not involved in the internal struggle within the Kaiser Wilhelm Gesellschaft, concerning the scientific standard of ecological research - in 
contrast to German limnology (cf. Lampert, 1992; Mollenhauer, 1984, 1993; Overbeck, 1986; Zirnstein, 1992).

Pringsheim visited the island, together with Franz Eilhard Schulze; they worked out an expertise which amalgamated all pertinent information: practical hints; scientific opportunities and chances of success; advantages for fishery research, a well-balanced consideration of competing marine stations - and they gave it a slightly nationalistic touch. They thus found the ideal mixture to convince the Prussian Ministry of Cultural Affairs to establish the new marine biological station in June, 1892. Pringsheim died two years later.

Acknowledgements. I am very grateful to Prof. Dr. Ernst Florey, Konstanz, for critically reading, and considerably improving, this paper.

\section{LITERATURE CITED}

Borchert, J., 1991. Hoffmann von Fallersleben. Verl. d. Nation, Berlin, 239 pp.

Cohn, F., 1895. Nathanael Pringsheim. - Ber. dt. bot. Ges. 13, 10-33.

Cohn, P. (Hrsg.) 1901. Blätter der Erinnerung - Ferdinand Cohn. Kern, Breslau, 266 pp.

Degen, H., 1974. Die Entstehung der Deutschen Botanischen Gesellschaft. - Naturw. Rdsch., Stuttg. $27,333-340$.

Degen, H., 1982. 100 Jahre Deutsche Botanische Gesellschaft. - Naturw. Rdsch., Stuttg. 35, 347-356.

Florey, E., 1995. Highlights and sidelights of early Biology on Helgoland. - Helgoländer Meeresunters. $49,77-101$.

Heincke, F., 1899. Die Einweihung des Nordseemuseums auf Helgoland verbunden mit einer Gedächtnisfeier für Nathanael Pringsheim. Littmann, Oldenburg.

Kornmann, P. \& Sahling, P.-H., 1984. Der Sorocarpus-Komplex. (Ectocarpaceae, Phaeophyta). Helgoländer Meeresunters. 38, 87-101.

Lampert, W., 1992. 100 Jahre Max-Planck-Institut für Limnologie in Plön. - Jb. Heimatk. Kreis Plön, $22,37-49$.

Mollenhauer, D., 1993. Vortrag anläßlich der Berufung von Prof. Dr. Otto Kinne zum 1. Präsidenten der "Nathanael Pringsheim-Gesellschaft". - Seevögel 14 (2), 21-24.

Mollenhauer, D., 1984. Gewässertypologien und A. Thienemanns Beitrag zur heutigen Limnologie. - Natur Mus., Frankf. 114, 192-198.

Mollenhauer, D. \& Lüning, K., 1988. Helgoland und die Erforschung der marinen Benthosalgen. Helgoländer Meeresunters. 42, 385-425.

Mollenhauer, D., 1993. Die "Süßwasserflora von Mitteleuropa". - Arch. Protistenk. 143, 7-12.

Overbeck, J., 1986. Von der biologischen Station vor 95 Jahren zum Max-Planck-Institut für Limnologie. In: 1000 Jahre Plön - 750 Jahre Lübisches Stadtrecht. Sönksen, Plön, 199-206.

Pringsheim, E. G., 1970. Ernst Georg Pringsheim (geb. 26. 10. 1881). - Medizinhist. J. 5, 125-137.

Schleiden, M. J., 1845. Methodologische Grundlage, vegetabilische Stofflehre, die Lehre von der Pflanzenzelle. Engelmann, Leipzig, 329 pp. (Die Botanik als inductive Wissenschaft 1).

Schleiden, M. J., 1846. Morphologie, Organologie. Engelmann, Leipzig, 614 pp. (Die Botanik als inductive Wissenschaft 2).

Schnarrenberger, C. \& Scholz, H. (Hrsg.), 1980. Geschichte der Botanik in Berlin. Colloquium Verl.; Berlin, 382 pp.

Stender, F. \& Freytag, H.-J., 1986. Geschichte der Stadt Plön. Sönksen, Plön, 335 pp.

Schumann, K., 1894. Nathanael Pringsheim. - Verh. bot. Ver. Prov. Brandenb. 36, XL-XLVIII.

Zirnstein, G., 1992. Otto Zacharias (1846-1916) und die Anfänge der limnologischen Forschung in Plön. - Jb. Heimatk. Kreis Plön 22, 167-178. 